\title{
The Assistance of Lecturers' Academic Administration in Improving the Quality of Higher Education at Indonesian School of Economics in Banda Aceh Indonesia
}

\author{
Masykur \\ Civil Servant at Coordinating Body for \\ Private Colleges Region Aceh, Aceh, Indonesia \\ yusrizal_fkipunsyiah@yahoo.co.id
}

\author{
Yusrizal \\ Department of Educational Administration \\ Syiah Kuala University, Indonesia \\ yusrizal_fkipunsyiah@yahoo.co.id
}

\author{
Niswanto \\ Department of Educational Administration \\ Syiah Kuala University, Indonesia \\ yusrizal_fkipunsyiah@yahoo.co.id
}

\begin{abstract}
The purpose of this study is to collect information about the assistance of lecturers' academic administration in improving the quality of college at the Indonesian School of Economics of Banda Aceh. This study uses qualitative approach with descriptive method. Data collection techniques are: interview, observation, documentation study and triangulation. Data analysis techniques with data reduction, data visualization, drawing conclusions and verification. The subjects of this study are lecturers and Head of Indonesian School of Economics of Banda Aceh. Based on the results of the research, it is found that: (1) the process of academic management planning in improving the quality of higher education at the Indonesian School of Economics of Banda Aceh, has been prepared properly and correctly in accordance with the conditions; (2) the assistance of lecturers' academic management in improving the quality of institution of higher education at Indonesian School of Economics of Banda Aceh has played its optimum role as seen in the learning media, having clear authority, and implementation of appropriate learning activities; and (3) assistance supervision of lecturers' academic administration in improving the quality of higher education at Indonesian School of Economics of Banda Aceh has been running well, so that the learning objectives can be achieved. Supervision is done in its entirety and systematically.
\end{abstract}

Keywords: academic administration, quality improvement

\section{INTRODUCTION}

The development of qualified human resources will give birth to intelligent and competitive people in continuing various tasks of national development. Improving the quality of human resources (HR) is an absolute thing that must be done in order to accelerate the achievement of national development goals as well as addressing global challenges. Through improving the quality of human resources which is a cultural process carried out through good planning in an organization.

In this regard, Siagian (2014) stated that: talking about human resource planning, the centre of attention is certain steps taken by management to better ensure that the organization has the right personnel to fill the right positions and jobs at the right time, all in order to achieve goals and objectives that have been and will be determined.

Higher education has a strategic function as a cultural centre, the development of science and technology and a moral force. These conditions will be managed well in the sense that they are able to demonstrate accountability, strong social responsibility, and the strength of higher education is more qualified and relevant. In an effort to improve the quality of higher education which is an important tip in answering the various needs of modern society. Because college is an institution for knowledge development that aims to produce good graduates.

The diversity of a tertiary institution related to higher education is very clear that this can be seen between public higher education and private higher education. The diversity of which is seen where higher education generally admit students with high average scores, when compared to other institutions of higher education. As stated in the Strategic Plan of the Directorate General of Higher Education of 2010-2014, namely the realization of a healthy and qualified education system, generating people of faith, devotion, intelligence and skill.

\section{METHODS}

This study attempts to describe the Assistance of Academic Management of Lecturers in Quality Improvement of Higher Education at the Indonesian School of Economics of Banda Aceh. Based on the scope of this study, the writers use descriptive method with a qualitative approach. In this case, the writers try to investigate and describe events in a natural way in accordance with what happened in the field.

This is as stated by Komariah (2014), qualitative research is a research approach that reveals certain social situations by describing the reality correctly, formed by words based on data collection techniques and analysis of relevant data obtained from scientific situations. Qualitative research methods are often referred to as naturalistic research methods, because their research is carried out in natural settings; also referred to as the ethnography method, because at first this method was more widely used for research in the field of cultural anthropology; referred to as a 
qualitative method, because the data collected and the analysis is more qualitative (Sugiyono, 2014).

Descriptive method is a method that is expected to describe indications, facts, and events as it stands with the aim to describe the nature of something at the time of the research and to examine the causes of a particular signs. Based on this understanding it can be understood that the descriptive method is a research that aims to describe the phenomena of a condition as it is. Problems related to education, as well as human behaviour, are mostly reported in descriptive form because they are simple and easy to understand without the need for complex statistical techniques.

\section{RESULTS}

Planning Process of Academic Administration in Improving the Quality of Higher Education

The college administration system is different from the administration in other institutions. In the university environment, there are different communities that are interrelated, namely students, lecturers, employees, and staffs. They are all governed by a leadership. Likewise, the management model applied in a university undergoes a change based on the development of the university.

Management in newly established tertiary institutions is different from the management in wellestablished old higher education. With this assumption, lecturers as the main part of higher education are necessary to be directly involved in managing tertiary institutions, both at the level of university, faculty, majors, study programs, as well as teams formed specifically for specific purposes. Therefore, the development of management capabilities is very important for lecturers.

If they are expected to contribute significantly to the management of higher education, their administrative and management capabilities need to be continuously improved. To support the management capabilities of the lecturers, it is essential to provide intensive and consistent trainings on general administration management, college management administration, formulation of educational strategies, the basics of educational planning, curriculum management, decision making, personnel management administration, human resources management, conflict management, the preparation of the program following its implementation, public relations, and so on.

The curriculum is a very important fundamental for generating high-quality students. A good curriculum is a curriculum whose contents focus on the students' abilities and are able to pique their interests to be creative and innovative. This is one of the most central roles of the lecturers. Meetings, seminars, workshops, and the like, held after curriculum renewal with the intention of uniting perceptions between lecturers about effective methods and ways to run the curriculum to succeed as expected. There will be harmony between the new curriculum and the development of lecturers' knowledge.
The Application of Assistance of Lecturers' Academic Administration in Improving the Quality of Higher Education

Pedagogical competence or the ability of lecturers to handle instructions is the backbone of the success of the education process in universities. This pedagogical expertise is related to good and proper teaching methods, so that the learning process can run smoothly and effectively. A lecturer, in addition to having aptitude in his scientific field, must also master teaching theories and techniques and their application in the instructions process in universities. Therefore, capacity improvement in this field is the main thing in developing lecturer's professionalism.

Some universities measure the quality of a faculty through the ability of its lecturers to manage the learning process. Likewise, the courses given to students are also suited to the pedagogical abilities of the lecturers. Lecturers are not only judged from proficiency in their field of study or the development of scientific theories, but also on their ability to teach and manage instructions in the classroom which involves their approaches, strategies, methods, and teaching style.

\section{The Supervision of Assistance of Lecturers' Academic Administration in Improving the Quality of Higher Education}

The implementation of Internal Audit of the Learning Process in each study program is carried out by members of Academic Quality Assurance Unit. In conducting the audit, the learning process needs to be documented for all its activities.

For this reason, various monitoring instruments are needed that must be filled in by each component involved in accordance with their functions and roles in the implementation of the learning process. The instrument consists of the following seven aspects:

a. Lecturer Monitoring Form, which is used by the lecturer secretariat to record the teaching loads and the hours the lecturers finish teaching. From this form, the number of teaching hours is detailed, both for each subject and all courses which are the responsibility of each lecturer.

b. Teaching Attendance Form, which is used by lecturers to record subjects, time, subject matter, class, number of students attendance, and signatures as proof of teaching. This form is also used by the lecturer secretariat to cross-check the data in the lecturer's teaching hours form.

c. Questionnaire Form, which is used by lecturer assistant to assess the quality of the lecturer learning process according to students. The quality of the learning process in terms of qualifications, competence, quality, and lecturer motivation, attractiveness and subject relevance, the effectiveness of the learning method, class management, student response, courses benefits in improving and developing student's knowledge according to the required level. The results of this questionnaire are mainly used to decide whether the lecturer is competent or not in teaching the courses given. 
d. Time Form for the Submission of Exam Questions, which is used by the Examination Team to log the date of submission and the type of subject matter tested. From this form, it can be seen whether the lecturer is on time or not in submitting the form.

e. Attendance List Form of Exam Supervision, which is used by the Examination Team to document attendance, leave, and absence of every lecturer in carrying out the task of supervising the examination. From this form, it can be seen whether the lecturer has carried out the task of monitoring well.

f. Counsel Form of Scientific Writing, which is used by lecturers to record counsel activities of every student who is under his supervision. It shows that the progress achieved in each counsel.

g. Class Guardianship Form, which is used by guardian lecturers to record problems, complaints, criticisms, and student proposals in the teaching process. It shows obstacles, motivation, and students' aspiration during the teaching process.

\section{DISCUSSION}

Higher education provides further education. Education unit organizes higher education is called a college, which can take the form of academy, polytechnics, specialized schools, institutes or universities. The form of higher education as referred to in Article 56 of Law Number 12 of 2012 concerning Higher Education is as follows: (1) university is an institution of higher education that organizes academic education and can hold vocational education and professional education in various categories of science and technology if it meets the requirements; (2) institute is an institution of higher education that administers academic education and can hold vocational education in a certain number of science and/or technology clusters if it meets the requirements, the institute can also organize professional education; (3) college is an institution of higher education that organizes academic education and can administer vocational education in a particular group of sciences and/or technology and if it meets the requirements, a college can hold professional education; (4) polytechnic is a an institution of higher education that administers vocational education in various clusters of science and technology if it meets the criteria, polytechnics can also organize professional education; and (5) academy is an institution of higher education that administers vocational education in one or several specific branches of science and technology.

Community Academy is an institution of higher education that administers vocational education at diploma level in one or several specific sciences and technology branches based on local wisdom or to meet special needs. With the diagnosis of the contemporary education world and the analysis of future education prospects, Tilaar proposes ten trends to reconstruct the National Education System that will support the modern industrial community, namely: (1) basic education; (2) curriculum; (3) instructions process; (4) education personnel; (5) education; (6) training and labour; (7) higher education; (8) further education; (9) education funding; and (10) decentralization of education and community participation, and education management.

Higher education as part of the national education system has a strategic role in educating the life of the nation and advancing science and technology by focusing and applying the values of humanities and the sustainable cultivation and empowerment of Indonesia. Higher education is administered by institution of higher education in accordance with Indonesian culture. Under the law Number 12 of 2012 article 5 states that: Higher Education aims at: (1) the development of students' potentials to become believers and God-fearing, healthy, knowledgeable, capable, creative, independent, skilled, competent; (2) cultured for the benefit of the nation; (3) generate graduates skilled at the branches of science and technology to fulfil national interests and boost the competitiveness of the nation; (4) good science and technology through research that takes into account and applies the value of humanities to be beneficial for; (5) the progress of the nation, as well as the progress of civilization and the welfare of mankind; and (6) the realization of Community Service based on reasoning and research work that is useful in fostering public welfare and educating the life of the nation.

Higher education is a source of innovation and solutions for the growth and development of the nation with the current development. As found in the UNESCO declaration, higher education has an important mission and function that is to contribute to sustainable development and the development of society as a whole. Institution of higher education is formal education units that carry out the mission of finding, discovering, and disseminating scientific truths through education and learning, research, and community service (Tridharmaof Higher Education). One of the most important indicators of the progress of higher education can be seen from its research (as an HR provider for research activities and useful research results). Under the act Number 12 of 2012, concerning Higher Education, Chapter I, Article 1 of the General Stipulation states, Tridharma of Higher Education, hereinafter referred to as Tridharma is the obligation of Higher Education to administer education, research and community service.

Based on the regulation of Indonesian minister of research, technology, and higher education number 13 of 2015 concerning the 2015-2019 Strategic Plan of the Ministry of Research, Technology and Higher Education has set a strategic goal which is then elaborated in 5 (five) strategic objectives in accordance with the problems that must be resolved during 2015 2019 period. The strategic objectives are: (1) increasing the quality of students and higher education learning; (2) expanding the quality of science and technology institutions and higher education; (3) bettering relevance, quality and quantity of science and technology and higher education resources; (4) strengthening relevance and productivity of research and development; and (5) boosting innovation capacity.

From the preliminary study conducted at the Indonesian School of Economics of Banda Aceh, there 
were found: (1) lecturers who did not have the academic position (functional position); (2) there were still lecturers who are not qualified but are still given the chance to be educators; and (3) lecturers who had not proposed for national lecturer's ID number which is a requirement to become a lecturer. As we know, the lecturer has the task inherent in the Tri Dharma of Higher Education, namely Teaching, Research and Service. One thing that is ironic in some private institutions of higher education under Coordinating Body for Private Colleges Region XIII of Aceh, lecturers by implementing the Tridharma of higher education while the legality requirements as lecturers have not been completed, this becomes a serious concern for the government particularly for the Coordinating Body for Private Colleges Region XIII of Aceh.

On the other hand, the number of students who continue to study at private institutions of higher education has swelled, thus requiring the number of lecturers to balance the ratio of students and lecturers. Private colleges in Aceh, especially at the Indonesian School of Economics of Banda Aceh, has not carried out a recruitment system for lecturers and administrative staff in a professional manner, the administration has not given encouragement and motivation to academic staff and lecturers to conduct good academic management so that to produce highquality private college.

\section{CONCLUSIONS}

The process of academic management planning in improving the quality of higher education at Indonesian School of Economics of Banda Aceh, has been prepared properly and correctly compliant with requirements. The academic management of lecturers in improving the quality of higher education at Indonesian School of Economics of Banda Aceh has carried out its functions to the maximum as stated in the learning media.

It can clearly be seen in the details of duties and authorities and the implementation of appropriate instruction activities. The supervision of assistance of lecturers' academic management in improving the quality of higher education at Indonesian School of Economics of Banda Aceh has gone well, so that the learning objectives are reached. Supervision is carried out exhaustively and systematically.

\section{REFERENCES}

[1] Indonesian Law Number 20 of 2003 concerning the National Education System. 2009. Jakarta Sinar Grafika.

[2] Komariah. 2014. Qualitatif Research Methods. Bandung: Alfabeta.

[3] Ministry of Research, Technology and Higher Education. 2017. Chart of the Number of Institutions of Higher Education. Retrieved December 7, 2017, from Excerpted https://forlap.ristekdikti.go.id/perguruan tinggi/ homegraphpt.

[4] National Accreditation Board for Higher Education. 2011. Self-Evaluation Guidelines: For Accreditation of Study Programs and Tertiary Institutions. Jakarta:
National Accreditation Board for Higher Education, Ministry of Education and Culture.

[5] Sugiyono. 2013. Combined Research Method. Bandung: Alfabeta.

[6] Siagian, S. P. 2014. Human Resource Management. Jakarta. Bumi Aksara.

[7] The Law Number 12 / 2012 about Higher Education. 2012. Jakarta: Fokus Media. 